\title{
THE RADIOCARBON WORLD ACCORDING TO WALLY
}

Irka Hajdas (i)

Laboratory of Ion Beam Physics, ETHZ, HPK H25, Otto-Stern-Weg 5, Zurich 8093, Switzerland

\section{INTRODUCTION}

Wallace Smith Broecker (1933-2019) grew up in Oak Park, Illinois, a village in Cook County adjacent to Chicago. From 1949 to 1952 he attended Wheaton College, but moved to graduate in 1953 from Columbia University, where he remained for a 66-year-long scientific career. In this time, he wrote many publications about the radioactive isotope of carbon. As the whole community knows him, Wally was a geochemist who found the passion of his life in research of the Earth system, how it functions, and how the various components are connected. However, one can certainly state that the first basis of his extraordinary scientific life was radiocarbon dating.

\section{Lamont Radiocarbon Laboratory}

Wally's summer job at the Lamont Radiocarbon laboratory in 1952, where he worked with the conventional counters, triggered his interest in Earth science and extended into a life-long position. His 1957 thesis at Columbia University, "Application of Radiocarbon to Oceanography and Climatic Chronology," outlined Wally's main interests. Most of them he followed throughout his life, and the ${ }^{14} \mathrm{C}$ dating was his most appreciated tool, which is evident from his publications (see Supplementary Material). He marveled at this isotope's utility and drew helpful ${ }^{14} \mathrm{C}$ cartoons in his Eldigio Press books (a publisher from Columbia University created to ensure the affordable price for the books). Known for his many achievements as a climate change visionary (Broecker 1975), Wally has also significantly impacted radiocarbon dating. In the early days of the radiocarbon, while at the Lamont ${ }^{14} \mathrm{C} \mathrm{lab}$, Wally explored various archives and carbon reservoirs. The Lamont Natural Radiocarbon Measurements published in Science, American Journal of Science, and finally in Radiocarbon journal give an overview of the variety of samples. His studies ranged from the ${ }^{14} \mathrm{C}$ in deep ocean water, corals and sediments to archeological samples, tree rings to the bomb ${ }^{14} \mathrm{C}$ in the biosphere, including human beings. Laboratory intercomparison and exchange between radiocarbon laboratories were essential. We will forever use the activity of 1890 wood from Palisades, NY, the Lamont campus (Broecker et al. 1959), as the baseline for 1950 calculations. The $\delta^{13} \mathrm{C}$ correction has been proposed in the same publication and revised after discussion with ${ }^{14} \mathrm{C}$ colleagues (Broecker and Olson 1961).

\section{Radiocarbon Ages of "Hand-Picked Foraminifera"-Wally and AMS ${ }^{14} \mathrm{C}$ Dating in Zurich}

Wally continued to use ${ }^{14} \mathrm{C}$ as a vital dating tool or a tracer in his research, and his collaborations from early days continued and evolved. His active approach amplified his ability to draw connections between research problems. Such was the case of AMS, i.e., the new technique that became available in 1977. Wally was eager to access this tool, which would finally allow him to measure the ${ }^{14} \mathrm{C}$ in foraminifera. With the possibility of dating a tiny amount of carbon, i.e., 10-20 mg, the "hand-picked foraminifera," ventilation of the paleo-ocean could now be traced. In the early 1980s, the already existing collaborations

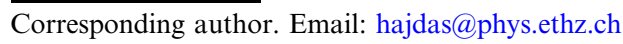




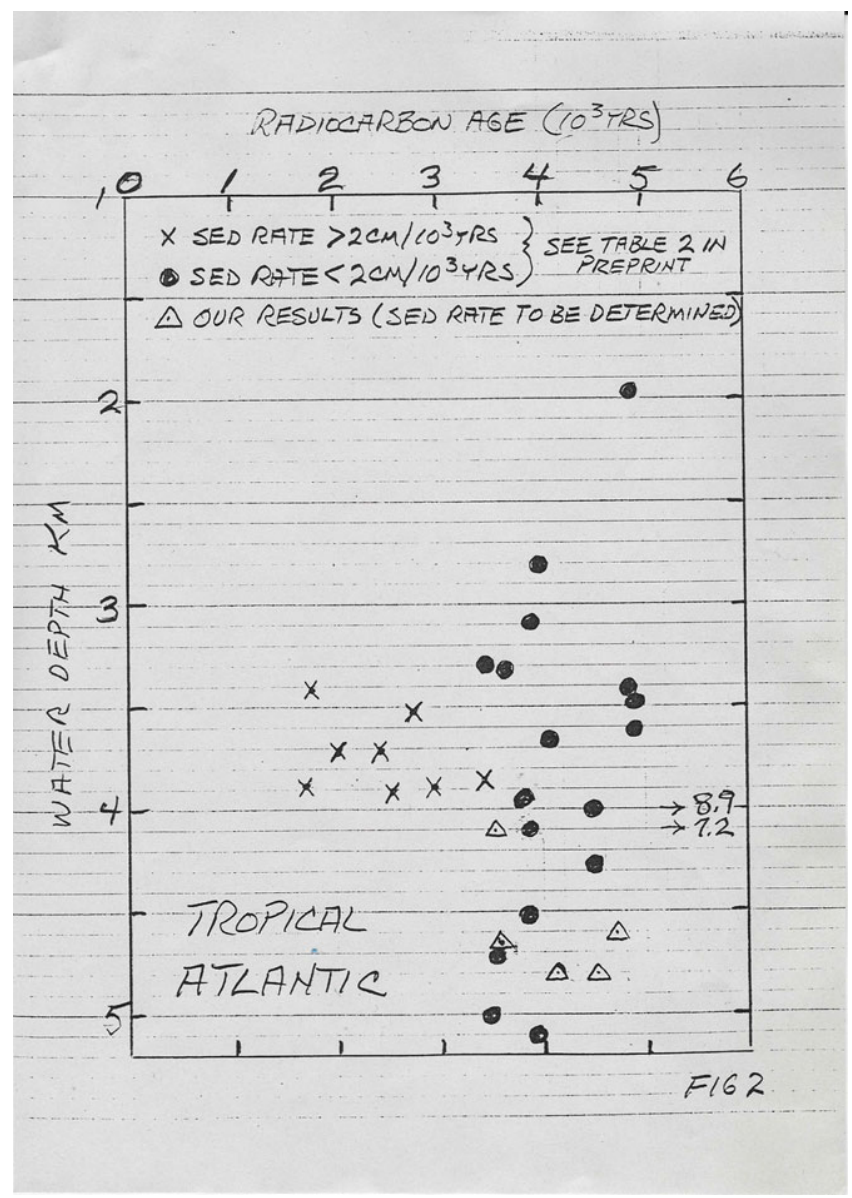

Figure 1 A hand-drawn figure for the manuscript in preparation (June 1991) with the results obtained so far showing the ratio of $\mathrm{CaCO}_{3}$ for various cores. The crosses are marking samples that arrived following the letter dated July 15, 1991.

with Hans Oeschger, the head of the counting radiocarbon laboratory at the University of Berne, and the inventor of a particularly precise version of the gas proportional counter, lead to a collaboration with the team of Willy Wölfli and Georges Bonani at ETH Zurich (Andree et al. 1984, 1986; Broecker et al. 1984). The involvement was essential for the $\mathrm{ETH}{ }^{14} \mathrm{C}$ laboratory and its participation in climate research.

Samples of foraminifera, tufa, water, ostracods, macrofossils, and wood from various archives worldwide and with different radiocarbon ages were analyzed. Moreover, research collaborators and PhD students of Wally were also sending samples to the ETH lab, which was then involved in dating climatic events and archives from around the globe (Broecker et al. 1988, 1998; Bond et al. 1992, 1993; Stute et al. 1995; Lin et al. 1996; Putnam et al. 2016).

From early 1989 I was lucky to be part of the ETH collaboration group and learn the basics of ${ }^{14} \mathrm{C}$ from Sue Trumbore, who was completing her $\mathrm{PhD}$ with Wally. After I began taking care of the samples sent from Lamont for graphitization and AMS analysis, Wally extended the 
authorship list. Yellow Lamont-stamped envelopes with drafts of manuscripts arrived quite frequently. Sometimes letters would come before the manuscript; occasionally, additional figures were sent after the manuscript. Wally was in constant exchange with his collaborators. The draft drawing sent in June 1991 (Figure 1) was a work in progress on the manuscript investigating carbonate dissolution in the deep sea and its effect on the ${ }^{14} \mathrm{C}$ ages of the core tops (Broecker et al. 1991).

It is an example of the many written exchanges, and it has a few graphic representations of data, which was so characteristic of Wally. The S-type arrows were typically pointing to the transition, data point, event. The figure (Figure 1) has been reproduced faithfully in the published manuscript (Fig. 10 in Broecker et al. 1991), but the very characteristic Wallyprint could not be shown. After 30 years, reading this reminds me how privileged I was to witness and be part of the dynamic research projects. It was the open-minded and inclusive approach that inspired many scientists, and I was one of them. All who were curious and interested in science were welcome in this endeavor. In his account of 60 years in science (Broecker 2012), Wally reflects on the research and people he encountered and with whom he worked. The book is a joyful reading, sparked by Wally's type of humor and stories. Reading it is a journey into the past but also the future because Wally Broecker, who looked at the history written in the archives, always focused on the future of our planet.

\section{SUPPLEMENTARY MATERIAL}

To view supplementary material for this article, please visit https://doi.org/10.1017/RDC. 2021.61

\section{REFERENCES}

Andree M, Beer J, Oeschger H, Broecker W, Mix A, Ragano N, Ohara P, Bonani G, Hofmann HJ, Morenzoni E, Nessi M, Suter M, Wolfli W. 1984. C-14 measurements on foraminifera of deep-sea core V28-238 and their preliminary interpretation. Nuclear Instruments \& Methods in Physics Research Section B-Beam Interactions with Materials and Atoms 5: $340-345$.

Andree M, Oeschger H, Broecker WS, Beavan N, Mix A, Bonani G, Hofmann HJ, Morenzoni E, Nessi M, Suter M, Wolfli W. 1986. AMS radiocarbon-dates on foraminifera from deep-sea sediments. Radiocarbon 28:424 428.

Bond $\mathrm{G}$, Broecker W, Johnsen S, Mcmanus J, Labeyrie L, Jouzel J, Bonani G. 1993. Correlations between climate records from North-Atlantic sediments and Greenland ice. Nature 365:143-147.

Bond $\mathrm{G}$, Heinrich $\mathrm{H}$, Broecker W, Labeyrie L, Mcmanus J, Andrews J, Huon S, Jantschik R, Clasen S, Simet C, Tedesco K, Klas M, Bonani G, Ivy S. 1992. Evidence for massive discharges of icebergs into the North-Atlantic Ocean during the Last Glacial Period. Nature 360: 245-249.
Broecker WS. 1975. Climatic change: are we on the brink of a pronounced global warming? Science 189:460-463.

Broecker WS. 2012. The carbon cycle and climate chance: memories of my 60 years in science. Geochemical Perspectives 1:221-340.

Broecker WS, Andree M, Wolfli W, Oeschger H, Bonani G, Kennett J, Peteet D. 1988. The chronology of the Last Deglaciation: implications to the cause of the Younger Dryas Event. Paleoceanography 3:1-19.

Broecker WS, Klas M, Clark E, Bonani G, Ivy S, Wolfli W. 1991. The influence of $\mathrm{CaCO}_{3}$ dissolution on core top radiocarbon ages for deep-sea sediments. Paleoceanography 6 : 593-608.

Broecker W, Mix A, Andree M, Oeschger H. 1984. Radiocarbon measurements on coexisting benthic and planktic foraminifera shellspotential for reconstructing ocean ventilation times over the past 20000 years. Nuclear Instruments \& Methods in Physics Research Section B-Beam Interactions with Materials and Atoms 5:331-339.

Broecker WS, Olson EA. 1961. Lamont radiocarbon measurements VIII. Radiocarbon 3:176-204. 
Broecker WS, Olson EA, Bird J. 1959. Radiocarbon measurements on samples of known age. Nature 183:1582-1584.

Broecker WS, Peteet D, Hajdas I, Lin J, Clark E. 1998. Antiphasing between rainfall in Africa's rift valley and North America's Great Basin. Quaternary Research 50:12-20.

Lin JC, Broecker WS, Anderson RF, Hemming S, Rubenstone JL, Bonani G. 1996. New Th-230/ $\mathrm{U}$ and $\mathrm{C}-14$ ages from Lake Lahontan carbonates, Nevada, USA, and a discussion of the origin of initial thorium. Geochimica Et Cosmochimica Acta 60:2817-2832.
Putnam AE, Putnam DE, Andreu-Hayles L, Cook ER, Palmer JG, Clark EH, Wang CZ, Chen F, Denton GH, Boyle DP, Bassett SD, Birkel SD, Martin-Fernandez J, Hajdas I, Southon J, Garner CB, Cheng H, Broecker WS. 2016. Little Ice Age wetting of interior Asian deserts and the rise of the Mongol Empire. Quaternary Science Reviews 131:33-50.

Stute M, Clark JF, Schlosser P, Broecker WS, Bonani G. 1995. A 30,000-yr continental paleotemperature record derived from noble-gases dissolved in groundwater from the San-Juan Basin, New-Mexico. Quaternary Research 43:209-220. 